\title{
The bronchoprotective effect of inhaled salmeterol in preschool children: a dose-ranging study
}

\author{
R.A. Primhak*, C.M. Smith*, S.C. Yong*, R. Wach*, M. Kurian*, R. Brown**, J. Efthimiou**
}

The bronchoprotective effect of inhaled salmeterol in preschool children: a dose-ranging study. R.A. Primhak, C.M. Smith, S.C. Yong, R. Wach, M. Kurian, R. Brown, J. Efthimiou. (C) ERS Journals Ltd 1999.

ABSTRACT: The optimal dose of salmeterol in infants and preschool children is not known. The aim of this study was to assess the bronchoprotective effect of different doses of salmeterol using methacholine-induced wheeze in children aged $<4$ yrs.

Children $<4$ yrs old with a history of recurrent wheeze underwent two methacholine challenges within 7 days. One hour before each challenge they were pretreated in double-blind fashion using a metered-dose inhaler and Babyhaler ${ }^{\mathrm{TM}}$ spacer. Placebo was given before one challenge, and either $25,50 \mathrm{or} 100 \mu \mathrm{g}$ of salmeterol before the other. Both the dose and treatment order were random. The provocative concentration of methacholine causing wheeze (PCwheeze) was measured on each occasion. Studies were terminated when wheeze occurred or arterial oxygen saturation $\left(S_{\mathrm{a}}, \mathrm{O}_{2}\right)$ fell below $91 \%$.

Of the 42 children enrolled, 33 completed the study. Two subjects refused the challenge test, two failed to return and five developed upper respiratory tract infections or wheeze between the two tests. The mean (range) age of the population was 27 (846) months. Ratios of $P C$ wheeze between treatment and placebo challenges were calculated for each dosage group. The treatment/placebo ratios $(95 \%$ confidence intervals $)$ were $1.2(0.6-2.4)$ for $25 \mu \mathrm{g}, 2.5(1.4-4.6)$ for $50 \mu \mathrm{g}(\mathrm{p}<0.01)$, and $4.0(2.1-7.4)(\mathrm{p}<$ $0.001)$ for $100 \mu \mathrm{g}$ doses.

In recurrently wheezy children aged $<4$ yrs a single dose of salmeterol between 25 and $100 \mu \mathrm{g}$ has a dose-dependent effect on methacholine-induced wheeze, and this is significantly different from placebo at 50 and $100 \mu \mathrm{g}$. This study suggests that the Babyhaler effectively delivers salmeterol to children $<4$ yrs of age and that doses between $50-100 \mu \mathrm{g}$ are efficacious.

Eur Respir J 1999; 13: 78-81.
*Dept of Paediatrics, Children's Hospital, Sheffield, UK. **Glaxo Wellcome Research and Development, Greenford, UK.

Correspondence: R.A. Primhak

University Department of Paediatrics

The Children's Hospital

Western Bank

Sheffield S10 2TH

UK

Fax: 441142755364

Keywords: Bronchial responsiveness infants

salmeterol

Received: March 181998

Accepted after revision August 151998

This study was funded by Glaxo Wellcome Research and Development, UK.
Salmeterol is a long-acting $\beta_{2}$-agonist which has recently been added to the therapeutic options available to treat asthma. It has been shown to reduce symptoms and improve lung function and quality of life in adults and children with asthma [1-5]. It has been recommended as supplementary treatment in adults and children over the age of 4 yrs when anti-inflammatory treatment is inadequate [6]. Its efficacy in children under the age of 4 yrs has not previously been assessed, and the optimum dosage has not been determined.

The aim of this dose ranging study was to assess the bronchoprotective effect of single doses of salmeterol given through a Babyhaler ${ }^{\mathrm{TM}}$ spacer device against methacholine challenge in recurrently wheezy children aged $<4$ yrs.

\section{Methods}

\section{Patients}

Children were recruited from the respiratory clinic population at the Children's Hospital, Sheffield. A child was eligible for the study if aged $<48$ months, with a physician- documented recurrent wheeze of at least one month duration, and without respiratory symptoms for at least one week prior to the first visit. Children were excluded from the study if they had suffered a serious respiratory tract infection in the preceding month, if they were receiving treatment for another systemic disorder, requiring maintenance oral corticosteroid treatment, or had congenital heart disease. Children receiving inhaled sodium cromoglycate or inhaled steroids were eligible for the study, but those receiving methylxanthines, ketotifen or antihistamines were excluded. Informed parental consent was obtained in all cases, and the study was approved by the South Sheffield Research Ethics Committee.

\section{Study design}

The study was designed as a double blind, randomized, two period, four treatment investigation. Each child was randomized to receive one of three possible doses of salmeterol, either 25,50 or $100 \mu \mathrm{g}$, as well as placebo. The child attended for two visits 2-7 days apart. In one visit the child received salmeterol in the assigned dose by metereddose inhaler (MDI) through a new Babyhaler ${ }^{\mathrm{TM}}$ spacer 
device and face mask (Allen \& Hanburys, Uxbridge, UK), and in the other visit placebo was given in the same manner. Four puffs of placebo, salmeterol $25 \mu \mathrm{g}$, or a mixture of the two were given, with the child breathing from the device for at least $15 \mathrm{~s}$ after each puff. The order of activeplacebo dosage and the dose administered were determined randomly using a code generated by a Glaxo Wellcome Research and Development computer program (PACT). Both the investigators and the parents were blind to the dosage and active-placebo information. Children who developed an intercurrent respiratory illness in the period between the two visits were excluded from analysis, as were children who defaulted on the second visit.

\section{Methacholine challenge}

One hour after receiving the salmeterol dose the child underwent a methacholine challenge using the method of Avital et al. [7] to measure the provocative concentration of methacholine causing wheeze (PCwheeze). Arterial oxygen saturation $\left(\mathrm{Sa}_{\mathrm{a}} \mathrm{O}_{2}\right)$ was monitored throughout with a Nellcor N-200 pulse oximeter (Nellcor, Bicester, UK), and auscultation of the chest and trachea was performed at the end of each stage. After baseline observations the child was given isotonic saline by nebulizer, then increasing concentrations of methacholine, starting at $0.03 \mathrm{mg} \cdot \mathrm{mL}^{-1}$, and increasing in doubling dilutions to a maximum possible concentration of $8 \mathrm{mg} \cdot \mathrm{mL}^{-1}$, given at 5 -min intervals. Each dose was given through a Hudson nebulizer (Temecula, CA, USA) connected to a compressed air source at 8 $\mathrm{L} \cdot \mathrm{min}^{-1}$ for 2 min tidal breathing by face mask. The study was terminated if wheezing was heard over the trachea or chest, or if the $\mathrm{Sa}_{\mathrm{a}} \mathrm{O}_{2}$ fell below $91 \%$. If crepitations or intercostal retractions were detected, subsequent doses were given for only $1 \mathrm{~min}$ each. The PCwheeze was taken as the concentration of methacholine at which wheeze or desaturation was observed.

\section{Statistics}

To allow for variation in the baseline PCwheeze between children, the efficacy of salmeterol was expressed as a ratio of active PCwheeze to placebo PCwheeze for each child. The ratios were log transformed to normalize them, and geometric means and 95\% confidence intervals were calculated. The effect of order of treatment was assessed prior to treatment group comparisons. The study was designed to have $80 \%$ power to detect a possible difference of two doubling doses of methacholine at 5\% significance. It was calculated that 18 patients would be needed in each arm of the study (54 evaluable patients).

\section{Results}

Forty-two eligible children were enrolled, of whom 33 completed the study. Two subjects refused the first challenge test, two refused the second challenge and five developed upper respiratory infection or wheeze in the interval between the two challenges. Because of the difficulty in recruitment it was decided to curtail the study at this point,
Table 1. - Treatment:placebo ratio of provocative concentration of methacholine causing wheeze (PCwheeze) in children receiving different doses of salmeterol

\begin{tabular}{lccc}
\hline & \multicolumn{3}{c}{ Dose } \\
\cline { 2 - 4 } & $25 \mu \mathrm{g}$ & $50 \mu \mathrm{g}$ & $100 \mu \mathrm{g}$ \\
\hline $\mathrm{n}$ & 10 & 12 & 11 \\
Male n & 8 & 10 & 10 \\
Age months* & 21 & 35 & 24 \\
& $(8-41)$ & $(9-45)$ & $(19-45)$ \\
PCwheeze ratio $^{\dagger}$ & 1.2 & 2.5 & 4.0 \\
& $(0.6-2.4)$ & $(1.4-4.6)$ & $(2.1-7.4)$ \\
\hline
\end{tabular}

*: median (range). ${ }^{\dagger}$ : geometric mean $(95 \%$ confidence intervals).

and the data were analysed, accepting the risk of inadequate power.

The median age of the patients was $27(8-46)$ months, and $28(85 \%)$ were male. Twenty-five children were receiving regular inhaled steroids, the median daily dose being $400 \mu \mathrm{g}$ (range 200-1,000 $\mu \mathrm{g}$ ). All patients had measurable PCwheeze below or at $8 \mathrm{mg} \cdot \mathrm{mL}^{-1}$ methacholine on both occasions. In $10 \%$ of occasions the test was terminated because $\mathrm{Sa}_{\mathrm{a}} \mathrm{O}_{2}$ fell below $91 \%$ before wheeze occurred. In one child there was clinically evident cyanosis which was transient, responding rapidly to oxygen-driven nebulized salbutamol.

There was no effect of order of treatment on outcome. The treatment/placebo ratios for the three treatment groups are shown in table 1. There was an incremental bronchoprotective effect with increasing dose of salmeterol, which was not significantly different from placebo at $25 \mu \mathrm{g}$, but was significant at $50(\mathrm{p}<0.01)$ and $100 \mu \mathrm{g}(\mathrm{p}<0.001)$. Examination of the log ratios by age did not suggest a cut-off below which the effect was lost, or any consistent relationship with age. Individual responses plotted by treatment group are shown in figure 1.

\section{Discussion}

Salmeterol is a long-acting $\beta_{2}$-agonist bronchodilator which has been used widely in adults and older children with asthma. It is particularly effective in the treatment of

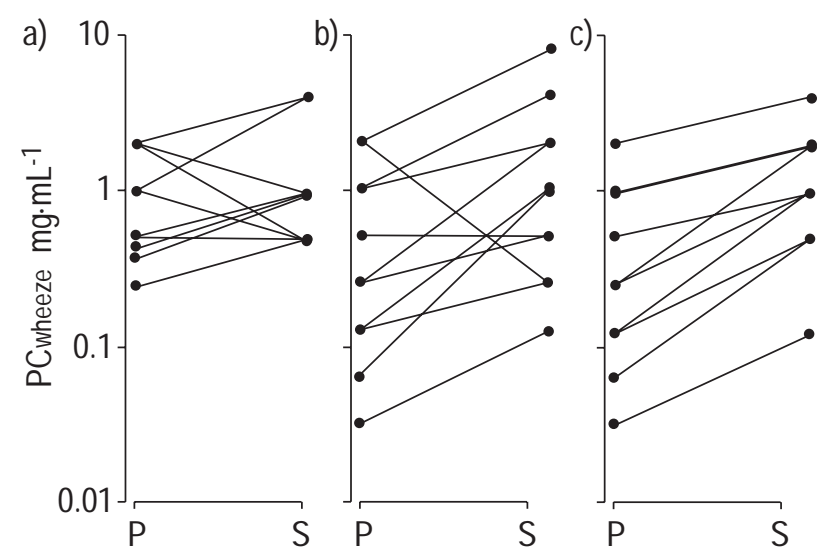

Fig. 1. - Individual changes in provocative concentration of methacholine causing wheeze (PCwheeze) between placebo $(\mathrm{P})$ and salmeterol (S) plotted by salmeterol dosage. a) $25 \mu \mathrm{g}$; b) $50 \mu \mathrm{g}$; and c) $100 \mu \mathrm{g}$. Note the logarithmic scale for $\mathrm{PC}$ wheeze. 
nocturnal symptoms $[3,8]$, exercise-induced asthma $[1,9]$, and as an alternative to increasing the dose of inhaled steroids in symptomatic patients [10]. It has not been studied in infants and young children. A model of a methacholine challenge was used to assess the effective bronchoprotective dose when administered through a Babyhaler ${ }^{\mathrm{TM}}$ spacer device.

The PCwheeze was chosen as the outcome measure because it was a relatively simple test to use, and was generally acceptable to parents and children. It has been shown to correlate well with provocative concentration causing a $20 \%$ fall in forced expiratory volume in one second (PC20) in older children [7, 11]. At the time of commencement of the study doubts were raised about the safety of the test, and in particular the risk of hypoxia [12]. As a safety precaution an $\mathrm{Sa}_{2} \mathrm{O}_{2}$ below $91 \%$ was incorporated as an alternative end-point, and it was found that with this proviso the test was safe and sensitive in the population studied.

Children below the age of 12-24 months with recurrent wheeze do not respond predictably to $\beta$-agonists in clinical settings. In these acutely wheezy infants some authors have found little or no clinical or physiological benefit from $\beta$-agonists [13-15], while others have observed more convincing effects [16-20]. If there is a reduced efficacy it is not because of a lack of either $\beta$-receptors or of smooth muscle, as bronchial reactivity to histamine, methacholine or distilled water can be attenuated in this age group by pretreatment with a $\beta$-agonist [21-25]. In keeping with these findings the present study did not observe any age effect on salmeterol efficacy within the study group, although the numbers were too small to exclude one with certainty. It is possible that the mechanism of wheeze in some young children is related more to inflammation and mucosal swelling than to smooth muscle constriction, explaining the inconsistency of observed response to $\beta$ agonists.

The Babyhaler has been evaluated in a number of clinical studies. Salbutamol delivered via the Babyhaler has been shown to protect against methacholine-induced bronchial reactivity in wheezy children aged 8-23 months [23] and 2-5 yrs [24]. In addition, significant improvement in lung function was shown in 29 out of 39 wheezy infants treated with salbutamol via the Babyhaler [26]. The present study confirms the usefulness of the Babyhaler as a delivery device for inhaled asthma therapy in young children, in that salmeterol given through a Babyhaler is protective against methacholine-induced bronchoconstriction in children aged between 8 months and 4 yrs. There appears to be a dose-response relationship, with a dose of $25 \mu \mathrm{g}$ giving only a $20 \%$ increase in PCwheeze (not significant) while the highest dose of $100 \mu \mathrm{g}$ caused a four-fold increase in PCwheeze. It is unlikely that this dose response was related to other confounders. There was no consistent age trend between the three groups, and the sex distribution was similar between groups.

No previous studies have looked at bronchoprotection with salmeterol in children $<4$ yrs of age, although there are a number of studies in adults and older children. The treatment/placebo ratios which were observed in the present study were lower than those observed for PD20 in adults by Higham et al. [27]. However, such comparisons can only be cautious due to a number of important differences including lung size, disease severity, concomitant medications and baseline level of bronchial reactivity of the two populations. At least two studies have been conducted in children with salmeterol $[28,29]$ which offer a more direct comparison. In a study by VERBERNE et al. [28] in children aged 7-16 yrs a bronchoprotective effect of 1.7 doubling doses was observed with salmeterol $50 \mu \mathrm{g} \mathrm{b.d}$. compared with salbutamol $200 \mu \mathrm{g}$ b.d. when studied $12 \mathrm{~h}$ post-dose. This is similar to the increase observed in the present study.

SimONs et al. [29] compared the bronchoprotective effects of salmeterol 25 and $50 \mu \mathrm{g}$, salbutamol $200 \mu \mathrm{g}$ and placebo $12 \mathrm{~h}$ post-treatment in children between 6 and 12 yrs of age. Both salmeterol 25 and $50 \mu \mathrm{g}$ produced a significant increase in $\mathrm{PC} 20$ compared with placebo (4.9-fold and 7.1-fold increases, respectively) $3 \mathrm{~h}$ post-treatment. The $50 \mu \mathrm{g}$ dose provided significantly better protection than the lower dose from $30 \mathrm{~min}$ to $12 \mathrm{~h}$ afterwards. These results support the current findings in that 50 and $100 \mu \mathrm{g}$ produced increased bronchoprotection compared with the $25 \mu \mathrm{g}$ dose, the effect $12 \mathrm{~h}$ post-dose was not examined.

The results of the present study should be interpreted with caution in terms of clinical efficacy, since evidence of bronchoprotection against methacholine does not mean that the drug will be effective in blocking episodes of wheeze due to other agents and stimuli. Clinical studies are indicated in this age group, and it is anticipated that doses of 50-100 $\mu \mathrm{g}$ would be appropriate for further assessment.

\section{References}

1. Green CP, Price JF. Prevention of exercise induced asthma by inhaled salmeterol xinafoate. Arch Dis Childhood 1992; 67: 1014-1017.

2. Lenney W, Pedersen S, Boner AL, Ebbutt A, Jenkins MM. Efficacy and safety of salmeterol in childhood asthma. Eur J Pediatr 1995; 154: 983-990.

3. Sarin S, Shami S, Cheatle T. Salmeterol in nocturnal asthma. Br Med J 1991; 302: 347-348.

4. Simons FE, Soni NR, Watson WT, Becker AB. Bronchodilator and bronchoprotective effects of salmeterol in young patients with asthma. J Allergy Clin Immunol 1992; 90: 840-846.

5. Britton M, Earnshaw J, Palmer J. A twelve-months comparison of salmeterol with salbutamol in asthmatic patients. Eur Respir $J$ 1992; 5: 1062-1067.

6. British Thoracic Society, National Asthma Campaign, Royal College of Physicians of London, British Association of Accident and Emergency Medicine, British Paediatric Respiratory Society, Royal College of Paediatrics and Child Health. The British guidelines on asthma management. 1995 review and position statement. Thorax 1997; 52: 1-21.

7. Avital A, Bar Yishay E, Springer C, Godfrey S. Bronchial provocation tests in young children using tracheal auscultation. J Pediatr 1988; 112: 591-594.

8. Fitzpatrick M, Mackay T, Driver H, Douglas N. Salmeterol in nocturnal asthma: a double blind, placebo controlled trial of a long acting inhaled $\beta_{2}$ agonist. $\mathrm{Br} \mathrm{Med}$ $J$ 1990; 301: 1365-1368.

9. Carlsen $\mathrm{KH}$, Roksund O, Olsholt $\mathrm{K}$, Nja F, Leegaard J, Bratten G. Overnight protection by inhaled salmeterol on exercise-induced asthma in children. Eur Respir J 1995; 8: 1852-1855.

10. Greening AP, Ind PW, Northfield M, Shaw G. Added salmeterol versus higher-dose corticosteroid in asthma patients with symptoms on existing inhaled corticosteroid. 
Allen \& Hanburys Limited UK Study Group (see comments). Lancet 1994; 344: 219-224.

11. Noviski N, Cohen L, Springer C, Bar Yishay E, Avital A, Godfrey S. Bronchial provocation determined by breath sounds compared with lung function. Arch Dis Childhood 1991; 66: 952-955.

12. Wilson N, Bridge P, Phagoo S, Silverman M. The measurement of methacholine responsiveness in 5 year old children: three methods compared. Eur Respir J 1995; 8: 364-370.

13. Lenney W, Milner AD. At what age do bronchodilator drugs work? Arch Dis Childhood 1978; 53: 532-535.

14. Prahl P, Petersen NT, Hornsleth A. Beta 2-agonists for the treatment of wheezy bronchitis? Ann Allergy 1986; 57: 439-441.

15. Alario AJ, Lewander WJ, Dennehy P, Seifer R, Mansell AL. The efficacy of nebulized metaproterenol in wheezing infants and young children. Am J Dis Children 1992; 146: 412-418.

16. Bentur L, Kerem E, Canny G, et al. Response of acute asthma to a beta 2 agonist in children less than two years of age. Ann Allergy 1990; 65: 122-126.

17. Bentur L, Canny GJ, Shields MD, et al. Controlled trial of nebulized albuterol in children younger than 2 years of age with acute asthma. Pediatrics 1992; 89: 133-137.

18. Kraemer R, Frey U, Sommer CW, Russi E. Short-term effect of albuterol, delivered via a new auxiliary device, in wheezy infants. Am Rev Respir Dis 1991; 144: 347-351.

19. Orlowski L, Zychowicz C, Migdal M, Gutkowski P. Effect of salbutamol on specific airway resistance in infants with a history of wheezing. Pediatr Pulmonol 1991; 10: 191-194.

20. Schweich PJ, Hurt TL, Walkley EI, Mullen N, Archibald LF. The use of nebulized albuterol in wheezing infants. Pediatr Emergency Care 1992; 8: 184-188.

21. O'Callaghan C, Milner AD, Swarbrick A. Nebulised salbutamol does have a protective effect on airways in children under 1 year old. Arch Dis Childhood 1988; 63: 479-483.

22. Prendiville A, Green S, Silverman M. Airway responsiveness in wheezy infants: evidence for functional beta adrenergic receptors. Thorax 1987; 42: 100-104.

23. Avital A, Godfrey S, Schachter J, Springer C. Protective effect of albuterol delivered via a spacer device (Babyhaler) against methacholine induced bronchoconstriction in young wheezy children. Pediatr Pulmonol 1994; 17: 281-284.

24. Clarke JR, Aston H, Silverman M. Delivery of salbutamol by metered dose inhaler and valved spacer to wheezy infants: effect on bronchial responsiveness. Arch Dis Childhood 1993; 69: 125-129.

25. Henderson AJ, Young S, Stick SM, Landau LI, LeSouef PN. Effect of salbutamol on histamine-induced bronchoconstriction in healthy infants. Thorax 1993; 48: 317323.

26. Kraemer R, Birner P, Modelska K, Casaulta Aebischer $\mathrm{C}$, Schoni MH. A new Baby Spacer device for aerosolised bronchodilator administration in infants with bronchopulmonary disease. Eur J Paediatr 1992; 151: 57-60.

27. Higham M, Sharara A, Wilson P, Jenkins R, Glendenning G, Ind P. Dose equivalence and bronchoprotective effects of salmeterol and salbutamol in asthma. Thorax 1997; 52: 975-980.

28. Verberne AA, Hop WC, Creyghton FB, et al. Airway responsiveness after a single dose of salmeterol and during four months of treatment in children with asthma. J Allergy Clin Immunol 1996; 97: 938-946.

29. Simons FE, Soni NR, Watson WT, Becker AB. Bronchodilator and bronchoprotective effects of salmeterol in young patients with asthma. J Allergy Clin Immunol 1992; 90: 840-846. 